\title{
Knowledge and Attitudes of Nursing Technical Secondary Schools' Students toward Acquired Immune Deficiency Syndrome (Aids) in El-Mansoura City
}

Dr. Nagat Said Habib, Dr. Hassan Abd El-Wahid, Dr. Mona Younes, Hala Ahmad Fouad

Professor of Community Health Nursing Faculty of Nursing Cairo University; professor of Family Medicine Faculty of Medicine Suez Canal University; Lecturer of Community Health Nursing Faculty of Nursing Port Said University; B.Sc, Mansoura University.

\begin{abstract}
Background: Acquired Immune Deficiency Syndrome (AIDS) epidemic has become one of the most important public health problems in recent times, and a serious health issue all over the world, particularly in low- and middle-income countries, which continues to grow. Aim: aim of study: the present study aimed to assess Knowledge and Attitudes of Nursing Technical Secondary Schools' Students toward Acquired Immune Deficiency Syndrome (AIDS) in EL-Mansoura city.Subject and Methods :A descriptive research design was utilized to conduct this study. The study Sample was carried on 255 students in the technical secondary schools of nursing in EL-Mansoura city. The data were collected using two tools: first tool was Structured Questionnaire Sheet which was composed of two parts: part one was Sociodemographic data sheet, part two was nursing students' Knowledge assessment and the $2^{\text {nd }}$ tool was Attitudes Scale. Results: of this study showed that, nursing students' knowledge level was satisfied (i.e. $\geq 60 \%$ ) in $62.0 \%$ of them. The majority of the studied nursing students had positive attitudes (i.e. 60 - 100\%) toward HIV/AIDS patients in $96.1 \%$ of them. An inverse correlation was observed between level of knowledge and attitude of the studied nursing students.Conclusion: The conclusion of this study was more than half of the nursing students had satisfied knowledge and the majority of them had positive attitudes toward HIV/AIDS.Recommendtions : The study recommended that updating knowledge of nursing students toward HIV/AIDS through talks/discussion organized by nursing schools and participation of nursing schools' students in national campaigns for HIV/AIDS awareness. To improve nursing students' willingness to care for people living with HIV/AIDS, particular emphasis should be placed on the training of nursing students as skilled nursing staff with positive attitudes towards people living with HIV/AIDS.
\end{abstract}

Key words: Knowledge, Attitude, Nursing students, HIV, AIDS. 


\section{INTRODUCTION}

Acquired Immune Deficiency Syndrome (AIDS) epidemic has become one of the most important public health problems in recent times, and a serious health issue all over the world, particularly in low- and middle-income countries, which continues to grow (World Health Organization (WHO), 2012) . In 2011, an estimated 2.5 million people were newly infected with the virus and more than 8 million people living with HIV were receiving antiretroviral therapy (ART). Another 7 million people need to be enrolled in treatment to meet the target of providing ART to 15 million people by 2015. At the end of 2013, it was estimated that the number of people living with HIV worldwide was 35 million and 11.7 million people had access to antiretroviral therapy in low- and middle-income countries (World Health Organization (WHO), 2012, 2014).

Egypt still maintains one of the lowest rates of HIV infections worldwide, not exceeding $0.1 \%$ of the population that estimate 2 cases for every 2000 citizen between 15 - 49 years of age (9200 are living with HIV in Egypt ). However, unsafe behaviors among at-risk populations set Egypt at risk of a broader epidemic. In 2008, there were 510 deaths attributed to HIV/AIDS and by the end of 2009, the National AIDS Program (NAP) reported 3,919 HIV cases detected in Egypt from which 2,920 were Egyptians. Among of these cases 1078 (27.5\%) developed AIDS (UNAIDS \& WHO, 2008; Taher \& Abdel- Hai, 2011).

The first case of HIV infection in Egypt was reported in the late '80s, the top reason for transmission of the disease (60 percent) was heterosexual intercourse and the most unusual reason was mother-child transmission, accounting for only 1.6 percent of the cases. HIV can be transmitted through unprotected sexual intercourse (vaginal or anal) or oral sex with an infected person, transfusions of contaminated blood, the sharing of contaminated needles, syringes or other sharp instruments, the transmission between a mother and her baby during pregnancy, childbirth and breast feeding (WHO, 2012).

Healthcare professionals including the nursing staff who have essential duties including collecting body samples (blood, urine, stool, sputum, etc.) and administering intravenous or intramuscular medication are usually performed with no barrier protections putting both patients and health care workers at risk. Also, in most developing countries, the lack of universal adherence to infection control protocols, poses a great risk for healthcare workers of occupational HIV infection at their daily work (Ehlers, 2006).

Fauci \& Folkers, (2009) stated that there is a growing evidence of success in HIV prevention worldwide and important success in the field of prevention towards HIV infection has been achieved by implementing a number of strategies including HIV testing and counseling, mass-media campaigns and education and behavior modification and the annual number of new HIV infections has globally decreased. 


\section{Significance of the Study:}

Nursing students as a subgroup of health care professionals exposed to an occupational risk of HIV infection due to direct contact with blood and body fluids during clinical practice, and have been reported to tend to have negative attitudes toward people living with HIV/AIDS such as fear of the possibility of becoming infected and death (Bektaş\&Kulakaç, 2007).

Nursing students with negative attitudes were less willing to care for people with HIV/AIDS compared to those with positive attitudes. Moreover, the higher the knowledge level regarding AIDS, the more positive were the attitudes and the higher was the willingness to care for AIDS patients (Mazloomy and Baghianimoghadam, 2008).

Nurses have a central role in prevention, care and treatment of people living with HIV/AIDS. Nursing students will acquire knowledge about HIV and AIDS through their nursing education and clinical training that will change their attitudes and influence their behaviors both in the prevention of transmission of the virus and positive attitudes for effective caring for people living with HIV/AIDS patients (Ouzouni \& Nakakis, 2012). Therefore, it is important to assess knowledge and attitudes toward HIV/AIDS among nursing students.

\section{AIM OF STUDY:}

The aim of this study was to assess Knowledge and Attitudes of Nursing Technical Secondary Schools' Students toward Acquired Immune Deficiency Syndrome (AIDS) in El- Mansoura city.

\section{SUBJECT AND METHODS:}

\section{Research design}

A descriptive research design was used to conduct this study.

\section{Setting}

This study was carried out in 3 technical secondary schools of nursing in El-mansoura city; Nursing school (EL-Mansoura health insurance hospital - girls), Nursing school (girls) and Technical secondary school for assistants of health services (boys and girls).

\section{Target population}

The Target population for this study was the nursing students who studied at the nursing schools that mentioned above.

\section{Sample size}

All nursing students (255 students) were studied in the above mentioned nursing schools at the time of data collection were included in this study. 


\section{Tools for data Collection:-}

To achieve the purpose of this study, data were collected through using 2 tools which were developed by the investigator and used to be pertinent to the current study. They are as the following:

Tool (1): This includes two parts.

Part (I): this part includes socio- demographic data sheet was used to collect data about: age, sex, school grade, residence, mother job and father job.

Part (II): this part contains 52 true/false statements that addressed the overall level of the student's knowledge about HIV/AIDS. Six subcategories identified the student's Knowledge about HIV/AIDS. These included (1) agent, immunology \& treatment (6 items), (2) clinical picture and manifestation (10 items), (3) high risk groups (7 items), (4) modes of transmission (14 items), (5) prevention (7items) and (6) Diagnostic Tests (8 items). Knowledge score was classified as follow: (a) correct answers of $60 \%$ or greater was classified as a satisfied knowledge level, (b) correct answers of less than $60 \%$ was classified as an unsatisfied knowledge level.

Tool (2): This tool is namely attitude scale; aims at evaluating nursing students' attitudes towards HIV/AIDS patients. The attitudes scale contained 22 statements, eight of the statements measured the students' attitudes toward empathy with HIV/AIDS patients; nine statements measured the students' attitudes toward providing direct care to HIV/AIDS patients, while the remaining five statements measured the students' attitudes toward isolation of HIV/AIDS patients. Attitude statements are valued on a 5 point likert scale ranging from (1 strongly disagree) to (5 strongly disagree). Attitude statements are valued with adjusted values, ranged between 20 and 100 (total score $=100$ ) where a lower score indicated a negative attitude (less than 60) and a high score indicated a positive attitude (between 60 and100).

\section{Content Validity and Reliability}

Validity was ascertained by a Jury consisting of five experts in the field of community health nursing. Necessary modifications were done according to the experts' opinions. Reliability of the tool was held on 29 students at the technical secondary schools of nursing in El-Mansoura city. Knowledge questionnaire had a Cronbach's alpha coefficient of $\mathbf{0 . 9 0}$ and attitude statements had a Cronbach's alpha coefficient of $\mathbf{0 . 7 5}$.

\section{Pilot Study}

The pilot study was carried out on $10 \%$ of the total sample to evaluate the reliability and applicability of tools and to estimate the proper time required for answering the questionnaire. They were excluded from the sample. Modification was done according to the results of pilot study.

\section{Field Work}

After obtaining the official permission to conduct the study and after finalization of the tools, the investigator visited each school prior to data collection to meet with the directors of schools and students individually and explained to them the purpose of the 
study; the consent of each eligible student was obtained before their participation. Those students were given structured questionnaire sheet and asked to fill it out. Data collection period extended 1 month from March to April 2014, 3 times a week, Sunday, Tuesday and Thursday. The questionnaires were distributed to the students at the end of their scheduled class sessions with cooperation of the lecturer in charge. The questionnaires were completed in class and took an average of 15-20 minutes to complete.

\section{Ethical Consideration:}

An official permission was taken from the dean of the faculty of nursing in Port Said University to the directors of the technical secondary schools of nursing in ELMansoura city, to ensure their cooperation and permission. The aim of the study has been explained to directors and students at schools before asking students to participate in the study, stressing the confidentiality of the collected data. The researcher emphasized that participation were absolutely voluntary and each student has the right to withdraw from the study at any time with no questions asked as well as confidentiality was assured.

\section{Statistical Analysis:}

The raw data were coded and transformed into coding sheets. The results were checked. Then, the data were entered into SPSS system files (Statistical Package of Social Services Version 16.0).Output drafts were checked against the revised coded data for typing and spelling mistakes. Finally, the analysis and interpretation of the data were conducted.

\section{The following statistical measures were used:}

- Descriptive statistics including frequency and distribution were used to describe different characteristics.

- Statistically analyses including: Chi- Square test, T-test, Monte Carlo test, One Way ANOVA and Fisher's exact test were used to test the significance of results of qualitative variables.

- A level of $\mathrm{p}<0.05$ was used to determine statistical significance.

\section{RESULTS:}

Table (1): shows socio-demographic characteristics of nursing students. The current study includes 255 students (86 males and 169 females), two thirds of them are female $(66.3 \%)$. The age of the study group ranges from 16 to less than 22years old, with a mean age of $17.5 \pm 0.68$. Majority of nursing students $(81.6 \%)$ are at the third grade of nursing school. More than half of them (63.9\%) are living in rural community.

Table (2): shows comparison between different schools regarding nursing students' knowledge toward HIV/AIDS. More than half (61.18\%) of nursing students identified that the curriculum doesn't contain information about HIV/AIDS. Majority of them (98.04\%) have information about HIV/AIDS. The main source of HIV/AIDS 
information is obtained by nursing students is school (98.04\%) and the less common source is family members $(0.2 \%)$. The common sources of information about HIV/AIDS are internet $(54.90 \%)$, radio \& T.V (54.12\%), hospitals \& health centers $(52.16 \%)$, friends $(30.20 \%)$ and magazines \& newspapers $(25.49 \%)$.

Table (3): shows frequency distribution of nursing students regarding their knowledge about causative agent, immunology and treatment of HIV/AIDS. More than half $(67.1 \%)$ of the nursing students reported that HIV and AIDS aren't the same thing. Majority of nursing students $(96.9 \%)$ said that AIDS is an infective disease. Majority of nursing students (92.2\%) mentioned that AIDS is caused by a virus. Majority of them $95.3 \%$ reported that HIV/AIDS decreases the human immune system. Less than half $47.1 \%$ of them said that there is a treatment for HIV/AIDS at present time.

Table (4): shows distribution of nursing students regarding their knowledge about modes of HIV/AIDS transmission. Slightly more than half $(54.9 \%)$ of nursing students said that HIV/AIDS cannot be transmitted by Pregnancy \& Labor. More than two thirds of them $(82.4 \%)$ mentioned that HIV/AIDS can be transmitted by shaking hands of infected person. More than two thirds of them reported that HIV/AIDS can be transmitted by blood transfusion $80.0 \%$, needles stick injury, syringes \& sharp instruments $76.5 \%$, sexual intercourse $87.8 \%$, semen/vaginal secretions $69.0 \%$, wounds \& surgical operations $58.8 \%$ and using the personal instruments for infected person (tooth brush - shaving instruments) $68.6 \%$.

Table (5): shows distribution of nursing students regarding their knowledge about methods of HIV/AIDS prevention. More than two thirds of them mentioned that using male or female condom $76.1 \%$, vaccine $74.5 \%$, eating healthy foods and taking vitamins \& antibiotics $67.8 \%$, properly disposing of needles and sharp instruments in a container $78.0 \%$, washing hands with soap, water \& disinfectants and wearing gloves $77.6 \%$ and disinfection and sterilization of all instruments that will be used again $79.2 \%$ are considered methods of HIV/AIDS prevention. Only $18.0 \%$ reported that Needles shouldn't be covered (recapped) immediately after use is considered a method of HIV/AIDS prevention.

Table (6): shows that distribution of nursing students regarding their attitudes toward empathy with HIV/AIDS patients. Less than half (46.3\%) of them is strongly agreed to sympathize with patients who get HIV/AIDS. Less than half (38\%) of nursing students are strongly disagreed to consider most HIV-positive patients as a stigma on community. More than half of them feel sympathy for people who get HIV/AIDS from infected blood transfusion $54.9 \%$ and feel sympathy toward the wife who gets HIV/AIDS from the sexual intercourse $78.8 \%$. Less than half $(49.0 \%)$ of them are strongly disagreed to end the friendship, if he found out that his/her friend infected with HIV/AIDS.

Table (7): shows that distribution of nursing students regarding their attitudes toward providing direct care to HIV/AIDS patients. More than two thirds $(74.5 \%)$ of nursing 
students are strongly agreed that HIV/AIDS patients have the right to the same quality of care as any other patient. Less than half $(27.1 \%)$ of them are strongly disagreed that Health care \& treatment shouldn't be provided for patients who get HIV/AIDS through I.V drugs addiction. More than two thirds (78.8\%) of them are strongly agreed that nurses should always provide a good care for patients with HIV/AIDS with following the standard precautions. Majority of them $(85.1 \%)$ are strongly agreed that Nurses should follow the standard precautions during blood transfusion to reduce the risk of infection with HIV/AIDS. Slightly more than half (53.7\%) of them are strongly agreed to do everything they could to give the best possible care to patients with HIV/AIDS. More than half $(61.6 \%)$ of them are strongly agreed to treat a family member infected with HIV/AIDS in a specialized hospital in treating AIDS.

Table (8): shows that distribution of nursing students regarding their attitudes toward isolation of HIV/AIDS patients. Only 3.5\% of nursing students are strongly disagreed to isolate patients in separate rooms at hospital away from other patients. Less than half $(27.1 \%)$ of them are disagreed to stay people living with HIV / AIDS at home and not go to work. Less than half $(48.6 \%)$ of them are strongly agreed to stay with a family member infected with HIV/AIDS at home with following the standard precautions. Less than half $(36.1 \%)$ of them are strongly agreed to keep Children who infected with HIV/AIDS out of school.

Table (9): shows the t-test analysis reveals that a statistically significant difference found in the mean of attitude scores between the rural and urban nursing students $(\mathrm{p}=0.045)$.

Table (10): shows distribution of nursing students according to their total knowledge score level. More than half of them (62.0\%) have satisfied knowledge.

Table (11): shows Distribution of nursing students according to their total attitude level. The majority of nursing students $(96.1 \%)$ have positive attitudes and only $3.9 \%$ of them have a negative attitude.

Table (12): shows Distribution of nursing students according to their different attitudes. The majority of nursing students $(97.2 \%)$ have positive attitudes toward empathy with HIV/AIDS patients. The majority of them $(98.0 \%)$ have a positive attitude toward providing direct care to HIV/AIDS patients. More than half of them $(68.3 \%)$ have a negative attitude toward isolation of HIV/AIDS patients.

Table (13): shows relationship between knowledge level of nursing students and their attitude. Chi-square test $(\boldsymbol{X})^{2}$ was conducted to test the significance of differences between knowledge and attitude categories. There are significant differences between different categories of two variables $(\mathbf{P = 0 . 0 4 2})$. It should be noted that the number of negative attitude increased when the knowledge was satisfied and vice versa. These findings are consistent with correlation analysis of the present study. 
The results show that a Pearson's correlation analysis was conducted between the total score of knowledge and attitude scores mean. As illustrated from figure 1. There is no significant correlation between them $(r=-0.05, P=0.399)$. This means that there is an inverse (Negative) relation between knowledge of nursing students and their attitudes toward HIV/AIDS and that means that there is an inconsistency.

Table (1): Socio-demographic characteristics of nursing students $(n=255)$.

\begin{tabular}{|l|l|l|}
\hline Characteristics & No. & \% \\
\hline $\begin{array}{l}\text { School grade: } \\
1^{\text {st }} \text { grade }\end{array}$ & 25 & \\
$2^{\text {nd }}$ grade & 22 & 9.8 \\
$3^{\text {rd }}$ grade & 208 & 9.6 \\
\hline Age: & & 81.6 \\
$16-<18$ year & 90 & \\
$18-<20$ year & 164 & 35.3 \\
$20-<22$ year & 1 & 64.3 \\
\hline Range. & $16.0-20.0$ & 0.4 \\
\hline Mean \pm SD. & $17.5 \pm 0.68$ & \\
\hline Sex: & & \\
Male & 86 & 33.7 \\
Female & 169 & 66.3 \\
\hline Residence: & & \\
Rural & 163 & 63.9 \\
Urban & 92 & 36.1 \\
\hline Father job: & & \\
Died & 17 & 6.7 \\
Retired-not working & 15 & 5.9 \\
Technical or manual & 107 & 42 \\
Gov. Employer & 116 & 45.5 \\
\hline Mother job: & 4 & 69.8 \\
Died & 178 & \\
Housewife & 73 & \\
Gov. Employer & & \\
\hline & & \\
\hline
\end{tabular}


Table (2): Comparison between different Schools regarding nursing students' Knowledge toward HIV/AIDS ( $\mathrm{n}=255)$.

\begin{tabular}{|c|c|c|c|c|c|c|c|}
\hline & \multicolumn{6}{|c|}{ Nursing school } & \multirow{3}{*}{ P value } \\
\hline & \multicolumn{2}{|c|}{$\begin{array}{c}\text { Nursing school } \\
\text { (El-Mansoura } \\
\text { health insurance } \\
\text { hospital) }\end{array}$} & \multicolumn{2}{|c|}{ Nursing school } & \multicolumn{2}{|c|}{$\begin{array}{l}\text { Technical secondary } \\
\text { school for assistants } \\
\text { of health services }\end{array}$} & \\
\hline & Yes \# & No \# & Yes \# & No \# & Yes \# & No \# & \\
\hline $\begin{array}{l}\text { The curriculum } \\
\text { contains } \\
\text { information } \\
\text { about } \\
\text { HIV/AIDS. }\end{array}$ & $69(69.7)$ & $1(0.6)$ & $30(30.3)$ & $0(0.0)$ & $0(0.0)$ & $155(99.4)$ & $0.000^{*}$ \\
\hline $\begin{array}{l}\text { You have } \\
\text { information } \\
\text { about } \\
\text { HIV/AIDS. }\end{array}$ & $70(28.0)$ & $0(0.0)$ & $30(12.0)$ & $0(0.0)$ & $150(60.0)$ & $5(100.0)$ & $0.394 *$ \\
\hline \multicolumn{8}{|c|}{ Source of Students' Information about HIV/AIDS } \\
\hline School. & $70(28.0)$ & $0(0.0)$ & $30(12.0)$ & $0(0.0)$ & $150(60.0)$ & $5(100.0)$ & $0.394 *$ \\
\hline $\begin{array}{l}\text { Hospitals \& } \\
\text { Health Centers. }\end{array}$ & $34(25.6)$ & $36(29.5)$ & $17(12.8)$ & $13(10.7)$ & $82(61.7)$ & $73(59.8)$ & $0.727+$ \\
\hline $\begin{array}{l}\text { Magazines } \\
\text { \&Newspapers. }\end{array}$ & $13(20.0)$ & $57(30.0)$ & $6(9.2)$ & $24(12.6)$ & $46(70.8)$ & $109(57.4)$ & $0.170+$ \\
\hline Radio \&T.V. & $40(29.0)$ & $30(25.6)$ & $14(10.1)$ & $16(13.7)$ & $84(60.9)$ & $71(60.7)$ & $0.630+$ \\
\hline Internet. & $31(22.1)$ & $39(33.9)$ & $16(11.4)$ & $14(12.2)$ & $93(66.4)$ & $62(53.9)$ & $0.087+$ \\
\hline Friends. & $19(24.7)$ & $51(28.7)$ & $10(13.0)$ & $20(11.2)$ & $48(62.3)$ & $107(60.1)$ & $0.778+$ \\
\hline $\begin{array}{l}\text { Family } \\
\text { Members. }\end{array}$ & $12(23.5)$ & $58(28.4)$ & $3(5.9)$ & $27(13.2)$ & $36(70.6)$ & $119(58.3)$ & $0.222 *$ \\
\hline $\begin{array}{l}\text { More than } \\
\text { One } \\
\text { source....... }\end{array}$ & $66(28.7)$ & $4(16.0)$ & $20(8.7)$ & $10(40.0)$ & $144(62.6)$ & $11(44.0)$ & $0.000 *$ \\
\hline
\end{tabular}

*, Fisher's Exact Test

+ , Pearson Chi-Square

\#, Number of nursing students and Percentage in between brackets. 
Table (3): Frequency Distribution of nursing students regarding their Knowledge about Causative Agent, Immunology and Treatment of HIV/AIDS ( $\mathrm{n}=255)$.

\begin{tabular}{|l|l|l|}
\hline & No. & $\%$ \\
\hline HIV and AIDS are the same thing. & 171 & 67.1 \\
No* & 84 & 32.9 \\
Yes & 8 & \\
\hline AIDS is an infective disease. & 247 & 3.1 \\
No & & 96.9 \\
yes* & 13 & \\
\hline AIDS is caused by a..... & 235 & 5.0 \\
I don't know & 3 & 92.2 \\
Virus* & 4 & 1.2 \\
Bacteria & & 1.6 \\
Parasite & 12 & \\
\hline HIV/AIDS decreases the human immune system. & 243 & 4.7 \\
No & & 95.3 \\
\hline Yes* & 135 & 52.9 \\
\hline There is a treatment for HIV/AIDS at present time. & 120 & 47.1 \\
\hline No & & \\
Yes* & & \\
\hline
\end{tabular}

*, Correct answer 
Table (4): Frequency Distribution of nursing students regarding their Knowledge about Modes of HIV/AIDS Transmission $(n=255)$.

\begin{tabular}{|c|c|c|}
\hline Modes of transmission & No. & $\%$ \\
\hline $\begin{array}{l}\text { Coughing \&sneezing. } \\
\text { No* } \\
\text { Yes }\end{array}$ & $\begin{array}{l}182 \\
73 \\
\end{array}$ & $\begin{array}{l}71.4 \\
28.6 \\
\end{array}$ \\
\hline $\begin{array}{l}\text { Blood Transfusion. } \\
\text { No } \\
\text { Yes* }\end{array}$ & \begin{tabular}{|l|}
51 \\
204 \\
\end{tabular} & $\begin{array}{l}20.0 \\
80.0 \\
\end{array}$ \\
\hline $\begin{array}{l}\text { Needles stick injury, syringes \&sharp instruments. } \\
\text { No } \\
\text { Yes* }\end{array}$ & \begin{tabular}{|l|}
60 \\
195 \\
\end{tabular} & $\begin{array}{l}23.5 \\
76.5 \\
\end{array}$ \\
\hline $\begin{array}{l}\text { Sexual Intercourse. } \\
\text { No } \\
\text { Yes* }\end{array}$ & \begin{tabular}{|l|}
31 \\
224
\end{tabular} & $\begin{array}{l}12.2 \\
87.8 \\
\end{array}$ \\
\hline $\begin{array}{l}\text { Semen/Vaginal secretions. } \\
\text { No } \\
\text { Yes* }\end{array}$ & \begin{tabular}{|l|}
79 \\
176 \\
\end{tabular} & $\begin{array}{l}31.0 \\
69.0\end{array}$ \\
\hline $\begin{array}{l}\text { Pregnancy \& Labor. } \\
\text { No } \\
\text { Yes* }\end{array}$ & $\begin{array}{l}140 \\
115 \\
\end{array}$ & $\begin{array}{l}54.9 \\
45.1 \\
\end{array}$ \\
\hline $\begin{array}{l}\text { Saliva, tears, sweat \& urine. } \\
\text { No* } \\
\text { Yes }\end{array}$ & $\begin{array}{l}174 \\
81 \\
\end{array}$ & $\begin{array}{l}68.2 \\
31.8 \\
\end{array}$ \\
\hline $\begin{array}{l}\text { Wounds \& surgical operations. } \\
\text { No } \\
\text { Yes* }\end{array}$ & \begin{tabular}{|l|}
105 \\
150 \\
\end{tabular} & $\begin{array}{r}41.2 \\
58.8 \\
\end{array}$ \\
\hline $\begin{array}{l}\text { Swimming pools \& toilet seats. } \\
\text { No* } \\
\text { Yes }\end{array}$ & $\begin{array}{l}155 \\
100 \\
\end{array}$ & $\begin{array}{r}60.8 \\
39.2 \\
\end{array}$ \\
\hline $\begin{array}{l}\text { Sharing food \& drink. } \\
\text { No* } \\
\text { Yes }\end{array}$ & $\begin{array}{l}176 \\
79 \\
\end{array}$ & $\begin{array}{l}69.0 \\
31.0 \\
\end{array}$ \\
\hline $\begin{array}{l}\text { Sharing clothes. } \\
\text { No* } \\
\text { Yes } \\
\end{array}$ & $\begin{array}{l}180 \\
75 \\
\end{array}$ & $\begin{array}{l}70.6 \\
29.4\end{array}$ \\
\hline $\begin{array}{l}\text { Some species of mosquitoes \&rats. } \\
\text { No* } \\
\text { Yes }\end{array}$ & $\begin{array}{l}150 \\
105 \\
\end{array}$ & $\begin{array}{l}58.8 \\
41.2 \\
\end{array}$ \\
\hline $\begin{array}{l}\text { Shaking hands of infected person. } \\
\text { No* } \\
\text { Yes }\end{array}$ & \begin{tabular}{|l|}
45 \\
210 \\
\end{tabular} & $\begin{array}{l}17.6 \\
82.4 \\
\end{array}$ \\
\hline $\begin{array}{l}\text { Using the personal instruments for infected person } \\
\text { (tooth brush - shaving instruments). } \\
\text { No } \\
\text { Yes* }\end{array}$ & \begin{tabular}{|l|}
80 \\
175 \\
\end{tabular} & $\begin{array}{l}31.4 \\
68.6\end{array}$ \\
\hline
\end{tabular}

*, Correct answer 
Table (5): Frequency Distribution of nursing students regarding their Knowledge about Methods of HIV/AIDS prevention $(n=255)$.

\begin{tabular}{|c|c|c|}
\hline Methods of prevention & No. & $\%$ \\
\hline $\begin{array}{l}\text { Using male or female condom. } \\
\text { No } \\
\text { Yes* }\end{array}$ & $\begin{array}{l}61 \\
194\end{array}$ & $\begin{array}{l}23.9 \\
76.1\end{array}$ \\
\hline $\begin{array}{l}\text { Vaccines. } \\
\text { No* } \\
\text { Yes }\end{array}$ & $\begin{array}{l}65 \\
190\end{array}$ & $\begin{array}{l}25.5 \\
74.5\end{array}$ \\
\hline $\begin{array}{l}\text { Eating healthy foods and taking vitamins \& antibiotics. } \\
\text { No* } \\
\text { Yes }\end{array}$ & $\begin{array}{l}82 \\
173\end{array}$ & $\begin{array}{l}32.2 \\
67.8\end{array}$ \\
\hline $\begin{array}{l}\text { Needles should be covered (recapped) immediately } \\
\text { after use. } \\
\mathrm{No}^{*} \\
\text { Yes }\end{array}$ & $\begin{array}{l}46 \\
209\end{array}$ & $\begin{array}{l}18.0 \\
82.0\end{array}$ \\
\hline $\begin{array}{l}\text { Needles and sharp instruments should be disposed } \\
\text { properly in a container to prevent needle stick. } \\
\text { No } \\
\text { Yes* }\end{array}$ & $\begin{array}{l}56 \\
199\end{array}$ & $\begin{array}{l}22.0 \\
78.0\end{array}$ \\
\hline $\begin{array}{l}\text { Washing hands with soap, water \& disinfectants and } \\
\text { wearing gloves. } \\
\text { No } \\
\text { Yes* }\end{array}$ & $\begin{array}{l}57 \\
198\end{array}$ & $\begin{array}{l}22.4 \\
77.6\end{array}$ \\
\hline $\begin{array}{l}\text { Disinfection and sterilization of all instruments that } \\
\text { will be used again. } \\
\text { No } \\
\text { Yes* }\end{array}$ & $\begin{array}{l}53 \\
202\end{array}$ & $\begin{array}{l}20.8 \\
79.2\end{array}$ \\
\hline
\end{tabular}

*, Correct answer 
Table (6): Frequency Distribution of nursing students regarding their Attitudes toward Empathy with HIV/AIDS patients $(n=255)$.

\begin{tabular}{|l|l|l|l|l|l|}
\hline & $\begin{array}{l}\text { Strongly } \\
\text { Agree \# }\end{array}$ & Agree \# & $\begin{array}{l}\text { Uncertain } \\
\#\end{array}$ & Disagree \# & $\begin{array}{l}\text { Strongly } \\
\text { Disagree \# }\end{array}$ \\
\hline $\begin{array}{l}\text { I'm sympathized with patients } \\
\text { who get HIV/AIDS. + }\end{array}$ & $118(46.3)$ & $97(38.0)$ & $15(5.9)$ & $11(4.3)$ & $14(5.5)$ \\
\hline $\begin{array}{l}\text { Most HIV-positive patients are } \\
\text { considered as a stigma on } \\
\text { community. } *\end{array}$ & $29(11.4)$ & $23(9.0)$ & $25(9.8)$ & $81(31.8)$ & $97(38.0)$ \\
\hline $\begin{array}{l}\text { Most people who have HIV/ } \\
\text { AIDS have only themselves to } \\
\text { blame. } *\end{array}$ & $48(18.8)$ & $39(15.3)$ & $53(20.8)$ & $86(33.7)$ & $29(11.4)$ \\
\hline $\begin{array}{l}\text { I think that people who are IV } \\
\text { drug users deserve to get HIV/ } \\
\text { AIDS. * }\end{array}$ & $64(25.1)$ & $56(22.0)$ & $59(23.1)$ & $49(19.2)$ & $27(10.6)$ \\
\hline $\begin{array}{l}\text { I feel sympathy for people who } \\
\text { get HIV/AIDS from infected } \\
\text { blood transfusion. }+\end{array}$ & $140(54.9)$ & $68(26.7)$ & $32(12.5)$ & $8(3.1)$ & $7(2.7)$ \\
\hline $\begin{array}{l}\text { I am sympathetic toward the } \\
\text { wife who gets HIV/AIDS from } \\
\text { the sexual intercourse. }+\end{array}$ & $201(78.8)$ & $39(15.3)$ & $4(1.6)$ & $8(3.1)$ & $3(1.2)$ \\
\hline $\begin{array}{l}\text { I feel very sad toward children } \\
\text { who infected with HIV/AIDS. } \\
+\end{array}$ & $227(89.0)$ & $25(9.8)$ & $3(1.2)$ & $0(0.0)$ & $0(0.0)$ \\
\hline $\begin{array}{l}\text { I will end the friendship, } \\
\text { If I found out that my friend } \\
\text { infected with HIV/AIDS. * }\end{array}$ & $9(3.5)$ & $16(6.3)$ & $20(7.8)$ & $85(33.3)$ & $125(49.0)$ \\
\hline
\end{tabular}

+ , positive Likert Statement.

*, Negative Likert Statement.

\#, Number of students and Percentage in between brackets. 
Table (7): Frequency Distribution of nursing students regarding their Attitudes toward Providing Direct Care to HIV/AIDS patients $(n=255)$.

\begin{tabular}{|c|c|c|c|c|c|}
\hline & $\begin{array}{l}\text { Strongly } \\
\text { Agree \# }\end{array}$ & Agree \# & Uncertain \# & Disagree \# & $\begin{array}{l}\text { Strongly } \\
\text { Disagree \# }\end{array}$ \\
\hline $\begin{array}{l}\text { I think that patients with } \\
\text { HIV/AIDS have the right to the } \\
\text { same quality of care as any other } \\
\text { patient. + }\end{array}$ & $190(74.5)$ & $47(18.4)$ & $7(2.7)$ & $6(2.4)$ & $5(2.0)$ \\
\hline $\begin{array}{l}\text { Health care \& treatment should be } \\
\text { provided only for patients who get } \\
\text { HIV/AIDS accidentally. } *\end{array}$ & $49(19.2)$ & $43(16.9)$ & $33(12.9)$ & $51(20.0)$ & $79(31.0)$ \\
\hline $\begin{array}{l}\text { Health care \& treatment shouldn't } \\
\text { be provided for patients who get } \\
\text { HIV/AIDS through I.V drugs } \\
\text { addiction. * }\end{array}$ & $31(12.2)$ & $28(11.0)$ & $26(10.2)$ & 101(39.6) & $69(27.1)$ \\
\hline $\begin{array}{l}\text { Patients with HIV/AIDS should be } \\
\text { treated with the same respect as } \\
\text { any other patient. + }\end{array}$ & $162(63.5)$ & $66(25.9)$ & $10(3.9)$ & $4(1.6)$ & $13(5.1)$ \\
\hline $\begin{array}{l}\text { I am willing to do volunteer work } \\
\text { with HIV/AIDS patients. + }\end{array}$ & $89(34.9)$ & $81(31.8)$ & $61(23.9)$ & $17(6.7)$ & $7(6.7)$ \\
\hline $\begin{array}{l}\text { I would like to do everything I } \\
\text { could to give the best possible care } \\
\text { to patients with HIV/AIDS. + }\end{array}$ & $137(53.7)$ & $87(34.1)$ & $23(9.0)$ & $5(2.0)$ & $3(1.2)$ \\
\hline $\begin{array}{l}\text { Nurses should always provide a } \\
\text { good care for patients with } \\
\text { HIV/AIDS with following the } \\
\text { standard precautions. + }\end{array}$ & $201(78.8)$ & $48(18.8)$ & $2(0.8)$ & $2(0.8)$ & $2(0.8)$ \\
\hline $\begin{array}{l}\text { Nurses should follow the standard } \\
\text { precautions during blood } \\
\text { transfusion to reduce the risk of } \\
\text { infection with HIV/AIDS. + }\end{array}$ & $222(87.1)$ & $29(11.4)$ & $1(0.4)$ & $0(0.0)$ & $3(1.2)$ \\
\hline $\begin{array}{l}\text { If a family member infects with } \\
\text { HIV/AIDS, we should treat } \\
\text { him/her in a specialized hospital in } \\
\text { treating AIDS. + }\end{array}$ & $157(61.6)$ & $80(31.4)$ & $9(3.5)$ & $9(3.5)$ & $0(0.0)$ \\
\hline
\end{tabular}

+ , positive Likert Statement.

*, Negative Likert Statement.

\#, Number of students and Percentage in between brackets. 
Table (8): Frequency Distribution of nursing students regarding their Attitudes toward Isolation of HIV/AIDS patients $(n=255)$.

\begin{tabular}{|l|l|l|l|l|l|}
\hline & $\begin{array}{l}\text { Strongly } \\
\text { Agree \# }\end{array}$ & Agree \# & Uncertain \# & $\begin{array}{l}\text { Disagree } \\
\#\end{array}$ & $\begin{array}{l}\text { Strongly } \\
\text { Disagree \# }\end{array}$ \\
\hline $\begin{array}{l}\text { People with HIV/AIDS should } \\
\text { be isolated in separate rooms at } \\
\text { hospital away from other } \\
\text { patients. }\end{array}$ & $141(55.3)$ & $74(29.0)$ & $17(6.7)$ & $14(5.5)$ & $9(3.5)$ \\
\hline $\begin{array}{l}\text { I think that it is better to people } \\
\text { living with HIV / AIDS to stay } \\
\text { at home and not go to work.* }\end{array}$ & $52(20.4)$ & $64(25.1)$ & $60(23.5)$ & $69(27.1)$ & $10(3.9)$ \\
\hline $\begin{array}{l}\text { If a family member infected with } \\
\text { HIV/AIDS, we can live with } \\
\text { him/her at home with following } \\
\text { the standard precautions. + }\end{array}$ & $124(48.6)$ & $84(32.9)$ & $35(13.7)$ & $4(1.6)$ & $8(3.1)$ \\
\hline $\begin{array}{l}\text { Young children should be } \\
\text { removed from the home if one of } \\
\text { the parents is HIV positive. * }\end{array}$ & $125(49.0)$ & $53(20.8)$ & $36(14.1)$ & $36(14.1)$ & $5(2.0)$ \\
\hline $\begin{array}{l}\text { Children who infected with } \\
\text { HIV/AIDS should be kept out of } \\
\text { school. * }\end{array}$ & $92(36.1)$ & $61(23.9)$ & $61(23.9)$ & $34(13.3)$ & $7(2.7)$ \\
\hline
\end{tabular}

+ , positive Likert Statement.

*, Negative Likert Statement.

\#, Number of students and Percentage in between brackets.

Table (9): T-Test: The Significance of differences in Knowledge and Attitude Scores Mean in different Categories of Sex and Residency.

\begin{tabular}{|l|l|l|l|l|l|l|l|l|}
\hline \multirow{2}{*}{ Categories } & \multicolumn{4}{|l|}{ Total Knowledge Scores Mean } & \multicolumn{4}{l|}{ Total Attitude Scores Mean } \\
\cline { 2 - 9 } & N & Mean & SD & P value & N & Mean & SD & P value \\
\hline Sex: & & & & & & & & \\
Male & 86 & 62.56 & 12.96 & 0.233 & 86 & 74.61 & 9.00 & 0.106 \\
Female & 169 & 61.79 & 10.89 & & 169 & 75.50 & 7.64 & \\
\hline Residency: & & & & & & & & \\
Rural & 163 & 61.35 & 10.74 & 0.113 & 163 & 74.91 & 8.59 & $\mathbf{0 . 0 4 5 *}$ \\
Urban & 92 & 63.30 & 12.97 & & 92 & 75.73 & 7.22 & \\
\hline
\end{tabular}

*, $P$ is significant at the 0.05 level. 
Table (10): Distribution of nursing students according to their total knowledge level $(\mathrm{n}=255)$.

\begin{tabular}{|l|l|l|}
\hline & No. & \% \\
\hline Unsatisfied Knowledge $(<\mathbf{6 0})$ & 97 & 38.0 \\
\hline Satisfied Knowledge $(\mathbf{2 0 )}$ & 158 & 62.0 \\
\hline
\end{tabular}

Table (11): Distribution of nursing students according to their total attitude level $(n=255)$.

\begin{tabular}{|l|l|l|}
\hline & No. & $\%$ \\
\hline Negative attitude $(<\mathbf{6 0})$ & 10 & 3.9 \\
\hline Positive attitude $(\mathbf{6 0}-\mathbf{1 0 0})$ & 245 & 96.1 \\
\hline
\end{tabular}

Table (12): Distribution of nursing students according to their different attitudes $(n=255)$.

\begin{tabular}{|l|l|l|l|l|}
\hline \multirow{2}{*}{ Attitude } & \multicolumn{2}{l|}{$\begin{array}{l}\text { Negative attitude } \\
(<60)\end{array}$} & \multicolumn{2}{l|}{$\begin{array}{l}\text { Positive attitude } \\
(\mathbf{6 0}-\mathbf{1 0 0})\end{array}$} \\
\cline { 2 - 6 } & No. & $\%$ & No. & $\%$ \\
\hline $\begin{array}{l}\text { Empathy with HIV/AIDS } \\
\text { patients. }\end{array}$ & 7 & 2.7 & 248 & 97.2 \\
\hline $\begin{array}{l}\text { Providing Direct Care to } \\
\text { HIV/AIDS patients. }\end{array}$ & 5 & 2.0 & 250 & 98.0 \\
\hline $\begin{array}{l}\text { Isolation of HIV/AIDS } \\
\text { patients. }\end{array}$ & 174 & 68.3 & 81 & 31.8 \\
\hline
\end{tabular}


Table (13): Relationship between knowledge of nursing students and their attitude $(\mathrm{n}=255)$.

\begin{tabular}{|l|l|l|l|l|l|}
\hline \multirow{2}{*}{ Attitude level } & \multicolumn{2}{|l|}{ Knowledge level } & \multirow{2}{*}{$\begin{array}{l}\text { Chi-Square } \\
\text { test }\end{array}$} \\
\cline { 2 - 5 } & $\begin{array}{l}\text { Unsatisfied level } \\
(\mathbf{n = 9 7})\end{array}$ & \multicolumn{2}{|l|}{$\begin{array}{l}\text { satisfied level } \\
(\mathbf{n = 1 5 8})\end{array}$} & \\
\cline { 2 - 5 } & No. & $\%$ & No. & $\%$ & \\
\hline Negative & 1 & 1.0 & 9 & 5.7 & $\begin{array}{l}\mathbf{X}^{\mathbf{2}}=\mathbf{6 . 2 9 1} \\
\text { MC } \mathbf{P = 0 . 0 4 2} *\end{array}$ \\
\hline Positive & 96 & 99.0 & 149 & 94.3 & \\
\hline
\end{tabular}

Figure (1):

\section{Correlation between Total Students' Knowledge and Attitude Scores Mean}

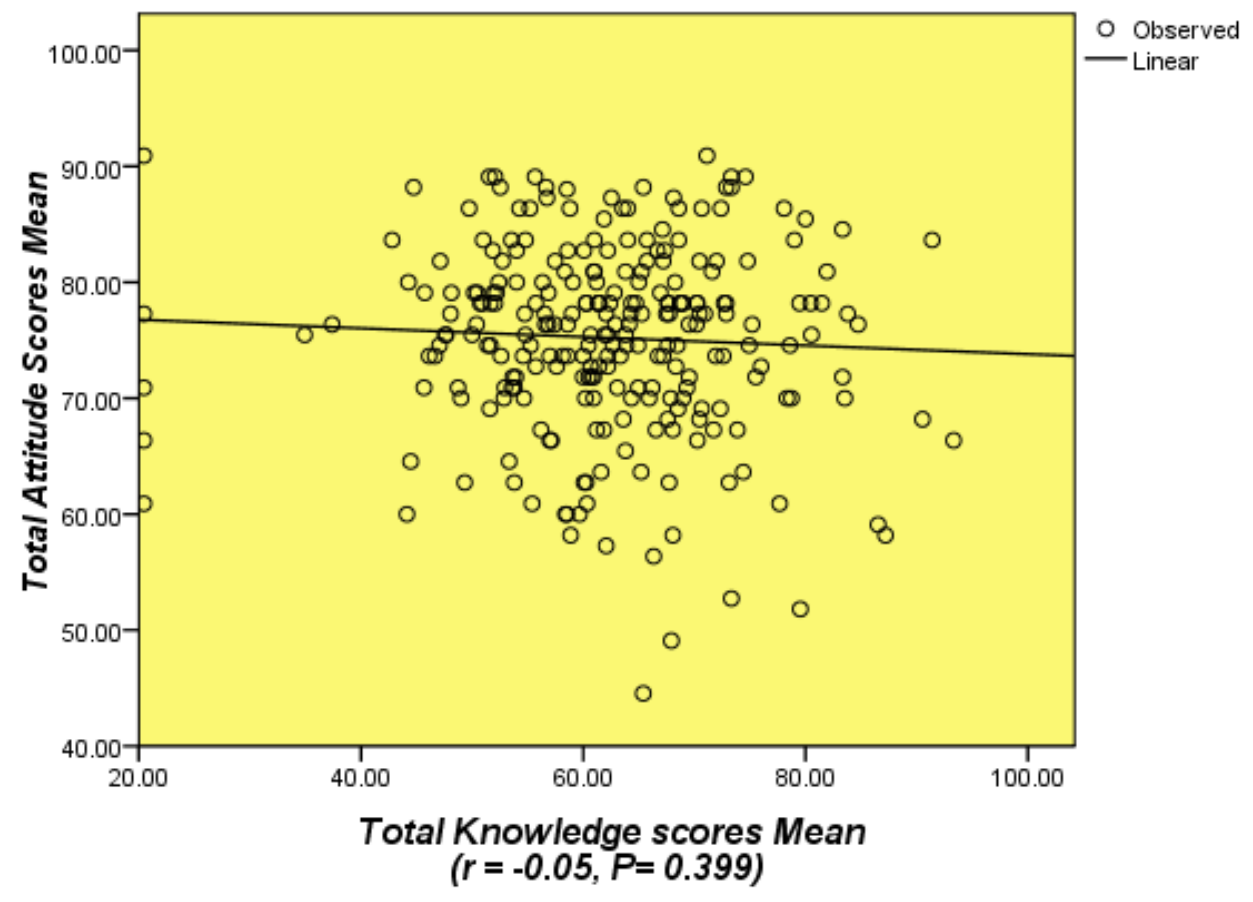




\section{DISCUSSION:}

Human Immune deficiency virus/ Acquired Immune deficiency syndrome (HIV/AIDS) is a serious health issue all over the world. No cure has been found for the disease yet. It was estimated that the number of people living with HIV worldwide was 35 million and 11.7 million people had access to antiretroviral therapy in low- and middleincome countries World Health Organization (WHO),, (2014).

Lack of knowledge, misconceptions and negative attitudes relating to HIV/AIDS can interfere with nurses' ability to provide quality care. Nurses are supposed to overcome their fears, prejudices and harmful attitudes towards all patients in their care so as to best help patients, patients' families and the larger community. Improving student nurses' knowledge is crucial to preventing HIV, improving care and reducing personal and social risk to the community International Council of Nurses, (2006).

The present study included 255 nursing students ( 86 males and 169 females). The age of the study group ranged from 16 to less than 22years old. The age mean of the study group was 17.5 ( $\mathrm{SD}=0.68)$ years. The majority of the study group was in the third grade of nursing school. More than half of the study group was living in a rural community.

In a survey of young people conducted in Egypt (a nationally representative sample of 15,029 young people aged 10-29y), the results showed that more than two thirds of respondents had heard of HIV/AIDS. Males had heard of HIV/AIDS than females and those over 15 were much more aware of HIV/AIDS than those aged 10-14. More than half of them with at least an elementary-school education had heard of HIV/AIDS and the majority of them in the workforce knew of HIV/AIDS Harbour and Barsoum, (2011).These results are in agreement with the findings of the present study, the majority of the study group reported that they had information about HIV/AIDS and this result may be due to the increase in knowledge sources of HIV/AIDS in the last decade.

The present study revealed that nursing students obtained information about HIV/AIDS from various sources, these findings may be due to the variety of HIV/AIDS' information sources everywhere such as educational curriculum and different media means. The results showed that the main source of HIV/AIDS information was school, although more than two thirds of the studied group said that the curriculum did not contain information about HIV/AIDS and the less common source of information was family members. In contrast with this, a survey of young people in Egypt revealed that the most common sources of information about HIV/AIDS are the media/cinema/radio (88.8\%), school (26.3\%), and friends (13.3\%)

Harbour and Barsoum,( 2011).

The present study revealed that students' knowledge level was satisfied regarding HIV/AIDS. This is considered crucial because nursing students as a subgroup of health care professionals should have accurate and adequate knowledge to safely 
perform their roles in caring for patients with HIV/AIDS. This result was in agreement with a similar study that was conducted in Malaysia in which 200 students from Xinjiang University and 200 students from Xinjiang Medical University were included. More than two thirds of the students had a good level of knowledge Maimaiti et al.,( 2010). In contrast with the present result, there are several studies that revealed lack of knowledge of students regarding HIV/AIDS in many countries including Turkey Bektas and Kulakac,( 2007), South Africa Madumo and Peu, 2006), Germany Lohrmann et al.,( 2000), and Jordan Petro-Nustas, Kulwicki, and Zumout,( 2002).

The present study revealed that there were many important misconceptions among the nursing students regarding general knowledge of HIV/AIDS. It is necessary to address these misconceptions by updating knowledge of nursing students toward HIV/AIDS through talks/discussion organized by nursing schools. The present results are supported by the results of the Malaysian study Maimaiti et al.,( 2010) and the Egyptian study Taher and Abdelhai,( 2011) that revealed that many misconceptions among the participants regarding general knowledge about HIV/AIDS.

The results of this study showed that the majority of nursing students had positive attitudes (i.e. 60 - 100\%) toward HIV/AIDS patients in $96.1 \%$ of them. According to Baron and Byrne (2000), attitudes are learned and are evaluative concepts associated with the way how people think, feel, and behave. This means that with proper education and the opportunity to work with patients with HIV/AIDS, the positive attitudes of students may increase, and the negative attitudes may decrease. In agreement with this study, an Iranian study by Aghamolaei, Tavafian, Hasani and Zare,( 2009). revealed that more than two thirds of health care personnel (nurses) had fairly positive attitudes toward patients with HIV. In contrast with this study, a study by Hassan \& Wahsheh (2011). showed that more than two thirds of Jordanian nurses had negative attitudes toward HIV/AIDS.

There was a statistical significant importance between knowledge level of the studied group and their attitude. These findings are consistent with correlation analysis of the present study. In contrast with this study, a study in Turkey (a descriptive crosssectional study was conducted at three nursing schools) revealed that there was no statistically significant relationship between mean scores in the attitude scale and mean scores in the knowledge scale (Akin, Mendi, Mendi and Durna,( 2013).

\section{CONCLUSION:}

\section{Based on the finding of the present study, it can be concluded that:}

nursing students' knowledge level was satisfied (i.e. $\geq 60 \%$ ) in $62.0 \%$ of them regarding the causative agent, clinical picture, treatment, identification of high risk groups, modes of transmission, methods of prevention, and diagnostic tests of HIV/AIDS and their major source of information about HIV/AIDS is the school, 
There were some important misconceptions among nursing students regarding general knowledge about HIV/AIDS, The majority of the studied nursing students had positive attitudes (i.e. $60-100 \%$ ) toward HIV/AIDS patients in $96.1 \%$ of them. There was a statistically significant difference in the mean of attitude scores between the rural and urban students $(\mathrm{p}=0.045)$. An inverse correlation was observed between level of knowledge and attitude of the studied nursing students.

\section{RECOMMENDATIONS:}

Based on the results of the present study, the following recommendations were suggested:

- Updating knowledge of nursing students toward HIV/AIDS through talks/discussion organized by nursing schools and participation of nursing schools' students in national campaigns for HIV/AIDS awareness.

- To improve nursing students' willingness to care for people living with HIV/AIDS, particular emphasis should be placed on the training of nursing students as skilled nursing staff with positive attitudes towards people living with HIV/AIDS.

- Infection control standards must be carried out effectively in the governmental and private hospitals.

\section{REFERENCES:}

WHO. (2014): Fact Sheet on HIV/AIDS-Media Centre. Updated November 2014, from World Health Organization, Available at: http://www.who.int/features/factfiles/hiv/en/november

WHO. (2012): Egypt, programme area, HIV/AIDS, Available at: http://www.emro.who.int/egy/programmes/hiv-aids.html

Taher E. and Abdelhai R. (2011): Nurses' knowledge, perceptions, and attitudes towards HIV/AIDS: Effects of a health education intervention on two nursing groups in Cairo University, Egypt-Journal of Public Health and Epidemiology Vol. 3(4), pp. 144-154, April 2011, available at: http://www.academicjournals.org/jphe

UNAIDS and WHO. (2008): Joint United Nations Programme on HIV/AIDS. Epidemiological fact sheet: Egypt. Available at: http:.//www.unaids.org/en/ Retrieved 28/07/2010.

Ehlers V.J. (2006): Challenges nurses face in coping with the HIV/AIDS pandemic in Africa. Int. J. Nursing. Stud., 43(6): 657-662. 
Fauci S. A. and Folkers K. G. (2009): Investigating to meet the scientific challenges of HIV/AIDS. Health Affairs, 28(6), 1629-1641. Retrieved from ProQuest with Full Text.

Bektas H. and Kulakac O. (2007): Knowledge and attitudes of nursing students toward patients living with HIV/AIDS (PLHIV): A Turkish perspective. AIDS Care, 19(7), 888-894.

Mazloomy S.S. and Baghianimoghadam M.H. (2008): Knowledge and attitude about HIV/AIDS of school teachers in Yazd, Islamic Republic of Iran. Eastern Mediterranean. Health J., 14(2): 292-297.

Ouzouni C. and Nakakis K. (2012): Knowledge, Attitudes, and Behaviors related to HIV and AIDS among Nursing Students in Greece. Health Science Journal. Volume 6, Issue 1, Page 130, January - March 2012.

International Council of Nurses, (2006): Reducing the Impact of HIV/AIDS on Nursing \& Midwifery Personnel. International Council of Nurses (ICN), Geneva. Available at: http://www.icn.ch/images/stories/documents/publications/guidelines/guideline_reduci ng_AIDS.pdf

Accessed at 20 August 2012.

Harbour C. and Barsoum G. (2011): SURVEY OF YOUNG PEOPLE IN EGYPT, Final Report. Chapter 2: Health, HIV/AIDS. P.40-41. West Asia and North Africa Office. 2010 The Population Council, Inc. available at: www.popcouncil.org/projects/SYPE/index.asp

Maimaiti N., Shamsuddin K., Abdurahim A., Tohti N. and Maimaiti R. (2010): Knowledge, attitude and practice regarding HIV/AIDS among University Students in Xinjiang. Global Journal of Health Science. Published by Canadian Center of Science and Education Vol. 2, No. 2; PP. 54-55, October 2010. available at www.ccsenet.org/gjhs

Madumo M. and Peu M. (2006): The views of undergraduate nursing students on caring for patients with HIV/AIDS. Curationis, 29(3), 87-96.

Lohrmann C., V“alimaaki M., Suominen T., Muinonen U., Dassen T. and Peate I. (2000): German nursing students' knowledge of and attitudes to HIV and AIDS: Two decades after the first AIDS cases. Journal of Advanced Nursing, 31(3), 696-703.

Petro-Nustas W., Kulwicki A. and Zumout A. (2002): Students' knowledge, attitudes, and beliefs about AIDS: A cross-cultural study. Journal of Transcultural Nursing, 13(2), 118-125. 
Baron A. and Byrne D. (2000): Social psychology (9th edition). Boston, MA: Allyn and Bacon.

Aghamolaei T., Tavafian S., Hasani L. and Zare S. (2009): Attitudes of HCW providers towards patients with HIV/AIDS in Bandar Abbas. Archives of Iranian medicine, 12(3), 298-301.

Hassan Z.M. and Wahsheh M.A. (2011): Knowledge and attitudes of Jordanian nurses towards patients with HIV/AIDS: Findings from a nationwide survey. Issues in Mental Health Nursing 32, 774-784.

Akin S., Mendi B., Mendi O. and Durna Z. (2013): sexually transmitted diseases and HIV. Turkish nursing students' knowledge of and attitudes towards patients with HIV/AIDS. Journal of Clinical Nursing, chap. 22, p. 3361-3371. 


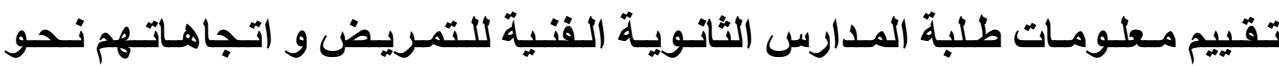

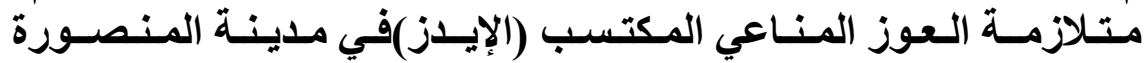

$$
\text { هالة أحمد فؤاد، د.نجاة سعيد حبيب ـ د.حسن على عبد الو احد ـ د.منى يونس }
$$

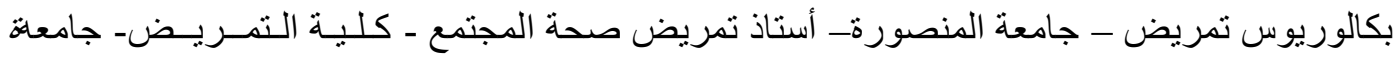

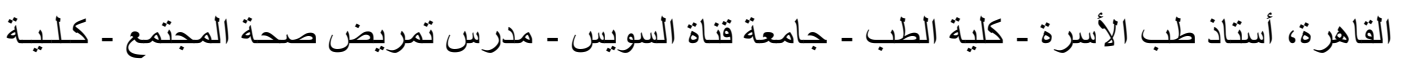

$$
\text { التمريض- جـامسعـة بورسعيد }
$$

\section{الـخـلاصــة}

لا تزال متلازمة العوز المناعي المكتسب( الإيدز) واحدة من أهم تحديات الصحة العامة في العالم، والتي في ازدياد مستمر و لا سيما في البلدان الفقيرة ومنوسطة الدخل. ويهدف البحث إلى تقييم معلومات طلبة المدارس الثنانوية الفنية للتمريض و اتجاهاتهم نحو متلازمة العوز المناعي المكتسب (الإيدز) في مدينة المنصورة. وكان المنهج المستخدم هو المنهج الوصفي. وقد أجريت هذه الدراسة علي 255 طالب وطالبة في المدارس الثانوية الفنية للتمريض في مدينة المنصورة. وتم تجميع البيانات باستخدام أداتين و هما : استمارة استبيان وهى مكونة من جز أين،

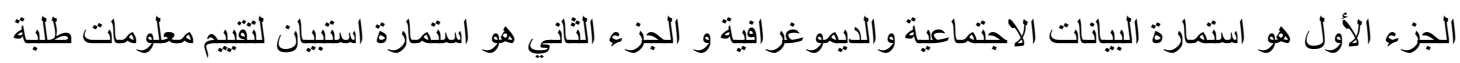

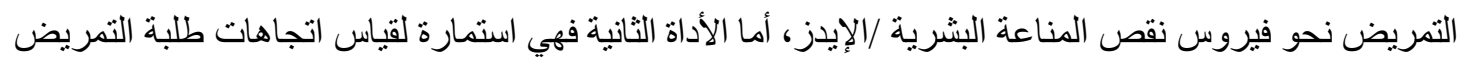
نحو فيروس نقص المناعة البشرية /الإيدز. وقد أسفرت الاراسة عن مجموعة من النتائج وكان من أهمها أن: أكثر من نصف طلبة التمريض لديهم معلومات مرضية عن فيروس نقص المناعة البشرية / الإيدز. الغالبية العظمى من طلبة التمريض لديهم اتجاهات إيجابية تجاه مرضى فيروس نقص المناعة البشرية / الإيدز. وقد لوحظ أن هناك علاقة عكسية بين معلومات طلبة التمريض واتجاهاتهم نحو فيروس نقص المناعة البشرية / الإيدز. وكاتت من أهم توصيات الدراسة الأتي :- ينبغي تحديث معلومات طلاب التمريض عن فيروس نقص المناعة البشرية / الإيدز من خلال المناقثات التي تنظمها مدارس التمريض ،ويجب أيضا مشاركة طلاب مدارس التمريض في الحملات

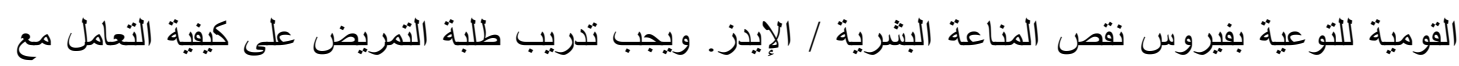
الأشخاص المصابين بفيروس نقص المناعة البشرية/ الإيدز وكذلك تدريبهم على كيفية تحسين اتجاهاتهم نحو هو لاء المرضى وتحسين نوعية الرعاية الصحية المقدمة إليهم.

الكلــــات الاسترشاديه : المعلومات، الاتجاهات، طلاب التمريض، فيروس نقص المناعة البشرية، متلازمة العوز المناعي المكتسب 